\title{
単層カーボンナノチューブを用いた新しい機能性素子
}

\section{Novel Functional Devices of Single-walled Carbon Nanotubes}

\author{
竹延 大志
}

Taishi Takenobu

\begin{abstract}
Single-walled carbon nanotubes are one of the candidate materials for the next generation electronics, such as printed, flexible, stretchable and wearable electronics due to their chemical stability, printability, flexibility, light-weight, and unique mechanical properties. In particularly, a combination of single-walled carbon nanotubes with electrolytes reveals rich and novel functionalities. This review describes recently demonstrated functional devices, such as inkjetprinted, extremely flexible, electrolyte-gated transistors.
\end{abstract}

Keywords: single-walled carbon nanotube, field-effect transistor, electrolyte, inkjet printing

\section{1. はじめに}

私が分子科学の世界に足を踏み入れたのは，今から約 20 年前の 1996 年である。偶然にもハロルド・クロトー, リ チャード・スモーリー, ロバート・カールの三人がフラー レン発見の業績に対してノーベル化学賞を受賞した記念す ベき年である。この年, フラーレンを用いた固体物理の研 究に憧れた私は, 岩佐義宏先生 (現 東京大学教授) の研 究室の扉を吒いた。以来, 今日までの間, 企業・大学と所 属を変えながら, 分子性固体を中心として固体物理やデバ イス物理の研究を続けてきた。

岩佐義宏先生の下でアルカリ金属やアルカリ土類金属を 用いた化学的キャリアドーピングを切り口に『分子性固体 の物性物理』の研究に没頭していたが, 博士課程修了後に 入社した企業では『分子の特徴を活かした機能性素子の実 現』が求められた。しかしながら，その当時の私には両者 の融合は極めて難しく，なかなか方向性が定まらずにいた。

時を同じくして, 当時ベル研究所に席を置いていたヤ ン・ヘンドリック・シェーンがトランジスタ構造を用いた 静電的キャリアドーピングにより超伝導を含む様々な電界 効果誘起相転移現象を実現し，大きな注目を浴びていた。 良く知られるように，これらの華々しい業績は捏造であり ほとんどの論文は取り下げられている。また，提案された
概念自体，決して彼のオリジナルではなかった。しかしな がら，静電的キャリアドーピング手法により物性を制御し 新機能を実現するアプローチは，私の悩みを氷解させる素 晴らしい切り口であった。

本稿では，本コンセプトに基づき筆者が提案・作製して きた様々な機能性素子を紹介する。特に，静電的キャリア ドーピングを突き詰めると 1879 年にヘルムホルツが発見し た電解質に特有な電気二重層（もしくは電気化学ドーピン

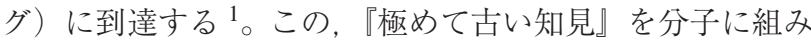
合わせた『新しい機能性素子』についても解説する。

\section{2. 無機材料と分子性固体の違い}

電解質を用いた素子の前に，通常の分子を用いた機能性 素子を紹介したい。良く知られるように，有機 EL はディ スプレイや照明として実用化されている。また，近年は電 界効果トランジス夕（field-effect transistor, FET） や太陽電 池・センサーなど様々な応用を目指した研究が活発に行わ れている。これら分子を用いた機能性素子は，基本的にシ リコンに代表される無機材料を用いた素子と類似構造を持 ち, 同様の原理で駆動されている。例えば, Figure 1 に示 す有機半導体を用いたMOS（Metal-Oxide-Semiconductor） トランジスタでは, 有機半導体／酸化物絶縁体／ゲート電
Bottom-contact type

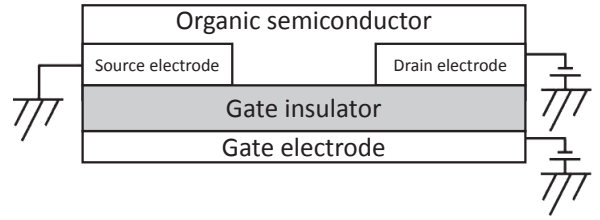

\section{Top-contact type}

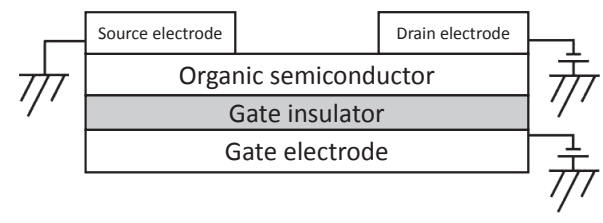

Figure 1. Typical device structures of organic field-effect transistors. 
極からなるコンデンサ構造を活かし半導体・絶縁体界面に 電荷を蓄積し（静電的キャリアドーピング）半導体の電気 抵抗を数桁にわたり制御する。この電気抵抗の変化を有機 半導体に作製された二つの電極（ソース電極・ドレイン電 極）を用いた抵抗測定から確認し，スイッチとしての機能 を発現する。このような動作原理は無機材料・有機材料間 で細かな違いはあるものの大枠では同じと言える2。しか しながら『分子の特徵を活かした機能性素子の実現』を目 指した試みも行われている。具体的には, 無機材料には無 い, 有機材料ならではの特徴である可溶性・可撓性に着目 し，これらを活かした新しいエレクトロニクスとして printed electronics $\cdot$ flexible electronics $\cdot$ stretchable electronics · wearable electronics などが提案されている ${ }^{3}$ 。本章では, 単層カーボンナノチューブ (single-walled carbon nanotube, SWCNT）に関する筆者らの研究成果を基に, これら新しい エレクトロニクスを紹介したい。

\section{Printed electronics}

\subsection{Printed electronics とは}

Printed electronics とは，文字通り『印刷された』素子を 意味する。印刷技術とエレクトロニクスの融合は，様々な 利点を生み出す。まず, 現在のシリコンを中心とするエレ クトロニクスを支える真空・微細加工技術は, その特徴と して材料使用効率が低く（<10\%), 様々な化成品を使用 するため, 省資源化・環境負荷低減が求められている。ま た，製造装置を常に高真空 $\left(<10^{-3} \mathrm{~Pa}\right)$ に保ち, 高温プロ セス（>100 $\mathrm{C} ）$ を多用する為, エネルギー消費も甚大で ある。これとは極めて対照的に，印刷技術は大気圧・室温 プロセスのため省エネルギーを実現する。特に, インク ジェット印刷は必要な材料を必要な個所にのみ滴下する技 術であるため原理的に材料使用効率が極めて高く （～100\%）大幅な省資源を実現する。事実，セイコーエプ ソンは液晶ディスプレイのカラーフィルタ製造工程にイン クジェット印刷を導入し, 二酸化炭素の排出量を $80 \%$ 低減 させたと報告している。加えて, 化学薬品の使用量も極限 まで低減され，低環境負荷にも大きく貢献できる。さらに， 資源・エネルギー・環境問題だけでなく，安価な設備投資 でのオンデマンドかつ大面積な素子作製が可能であり，大 幅な低コスト化・競争力向上のみならず小規模企業の参入 可能性も広がる。

このような printed electronics を実現するには, 半導体材 料をインク化する必要がある。基本的に, 材料の融点は結 合のエネルギーで決定する為, 共有結合もしくはイオン結 合が主である無機材料の融点は数百 ${ }^{\circ} \mathrm{C}$ であり, ナノ粒子化 する以外にインクに相当する溶液や分散液を作製できない。 これとは対照的に，分子性固体は分子間の結合が比較的弱 いファンデルワールス相互作用であり，適切な有機溶媒を 選択すれば溶液や分散液が低温 $\left(<100^{\circ} \mathrm{C}\right)$ で得られる。こ
のようなコンセプトの基, 様々な印刷技術を用いた素子 (特にトランジスタ) 作製が活発に試みられている。本節で は，一例として SWCNT を用いた printed electronics を紹介 する。

\subsection{SWCNTトランジスタ}

説明するまでもなく，SWCNT は炭素原子だけからなる 円筒状の物質であり，グラフェンシートを丸めた構造を持 つ 4-6。SWCNTを『分子』と考えるか否かは議論が分かれ るところであるが，SWCNT 間の相互作用は前述のファン デルワールス相互作用であり，広い意味では分子性固体の 類似物質と考えられる。筒の太さは $1 \mathrm{~nm}$ を切るものから $10 \mathrm{~nm}$ 以上のものまで存在し, 長さは数ミクロンから最近 では $1 \mathrm{~mm}$ を超える長さも実現している。つまり，微細加 工技術の限界を超えた極細ワイヤーであり，ナノテクノロ ジーの基幹物質として非常に多くの研究が行われている。 加えて, SWCNT は構造（直径や巻き方）により金属にも 半導体にも成り得る事が知られている7。そのため, 特に 半導体的な SWCNT は短チャンネル効果を軽減させた次世 代高速トランジスタ材料として近年でも注目されており, 国際半導体技術ロードマップ 2013 年版（ITRS2013）にお いて高移動度のチャネル代替材料に挙げられている。

SWCNT を用いたトランジスタは, 大きく分けて 2 種類 存在する。一つは, 1 本もしくは 1 束の半導体ナノチュー ブを用いたナノスケールのトランジスタであり，この様な デバイスは 1998 年から研究がスタートしている ${ }^{8}$ 。前述し た構造上の利点に加え，キャリアの無散乱走行（バリス ティック伝導）に基づく超高速動作や極めて安定な炭素間 共有結合が実現する高い電流駆動能力への期待も高く，ポ ストシリコンエレクトロニクスとして近年でも注目されて いる。これに対して，SWCNT 薄膜を利用したトランジス 夕が 2003 年に提案された ${ }^{9}$ 。このような薄膜では, SWCNT 間をキャリアが飛び移る（ホッピング伝導）ためバリス ティック伝導は表に顔を出さない。しかしながら, SWCNT の優れた伝導特性を反映し，トランジスタのスイッチング 速度の目安となる移動度が $100 \mathrm{~cm}^{2} / \mathrm{Vs}$ を大きく越える 10,11 。 この值は，既報の有機材料と比べると一桁から二桁は大き い值である。特に重要な点は，このような優れた伝導特性 が網目状（ネットワーク状）のアモルファス膜で実現され ている事である。印刷法は低コスト・省資源化・低環境負 荷の観点からは極めて優れているが，真空蒸着技術などに 比べ高い結晶性を有する薄膜作製が難しく，同一材料でも 印刷薄膜は低い特性となる傾向がある。このような状況に 対して，アモルファス膜において優れた特性が得られる SWCNT は印刷法に最適な半導体材料であると考え研究を 開始した。 

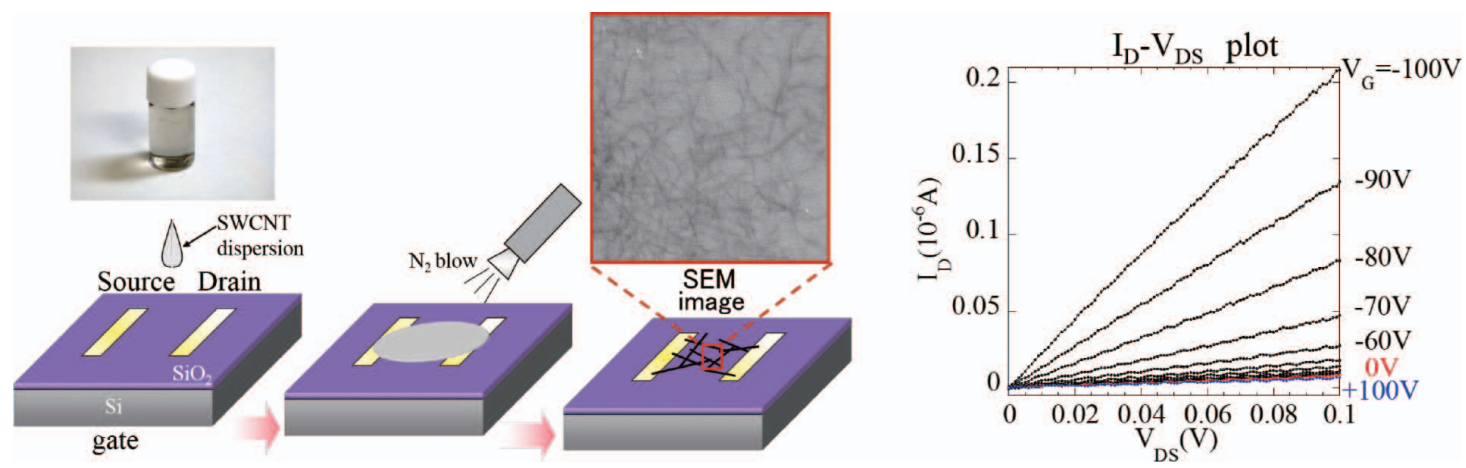

Figure 2. Solution processed SWCNT thin film transistor.
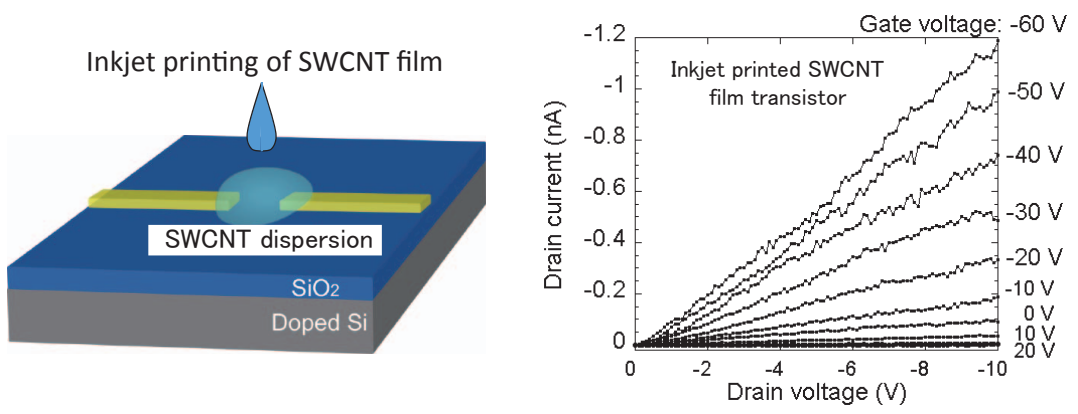

Figure 3. Inkjet printing of SWCNT thin film transistor.

\subsection{SWCNT printed トランジスタ}

2003 年に報告された初めての SWCNT 薄膜トランジスタ は, 絶縁膜 $\left(\mathrm{SiO}_{2}\right)$ 上に化学気相成長させた SWCNT 薄膜 を用いており, このままでは印刷技術の導入は難しい。そ こで我々は, 印刷法が導入可能な SWCNT インクによるト ランジスタ作製に白石誠司先生（現 京都大学教授）と共 同で着手した。具体的には，高温で合成した SWCNT 凝集 体をDMF（dimethylformamide）に分散させインク化し，基 板上へ滴下・乾燥した。実にシンプルな方法ではあるが ネットワーク状のSWCNT 薄膜作製に成功し, 最初の SWCNT 薄膜トランジスタの報告から 1 年遅れた 2004 年に は世界に先駆けた液相プロセスによる SWCNT 薄膜トラン ジスタを実現した (Figure 2) ${ }^{12}$ 。次のステップとして，イ ンクジェット法を用いたトランジスタ作製にブラザー工業 株式会社と共同で成功している (Figure 3) ${ }^{13}$ 。具体的には, ピエゾアクチュエータ方式ヘッドを有するブラザー工業株 式会社製のインクジェット装置を用いて製膜に挑戦した。 このインクジェットヘッドは, インク流路やノズルプレー トにセラミックを多用したヘッドであり，民生用プリンタ に搭載されたインクジェットヘッドに比べて有機溶剤など に対する耐性が高い。しかしながら，上述のDMFを用い た分散液は様々な悪影響を及ぼす可能性があるため, 本実 験では界面活性剂を用いた水溶性 SWCNT インクを使用し た。SWCNT 分散液はインクジェット法を用いてのパター ニングが十分可能であり，1つの液滴を電極間に滴下する だけでなく, 複数の液滴を電極間の異なる位置に滴下した
マルチチャンネルデバイスの作製や同一箇所に滴下した膜 密度制御にも成功しており，まさにSWCNT printed トラン ジス夕の実現である。

その後, 現在までに世界中の研究グループが様々な印刷 法を用いた SWCNT 薄膜トランジスタ作製を報告している が，大きな問題が残されていた。そもそも， SWCNT は構 造により金属にも半導体にもなり得るため, その集合体は 両者の混合物となる。その為, SWCNTの膜密度が大きす ぎると金属的 SWCNT によるネットワークが形成され半導 体的な伝導特性が失われる。一方で, 膜密度が低すぎると 十分な電流が得られない場合や電流が流れない可能性もあ る。つまり, SWCNT 薄膜トランジスタを作製するには膜 密度の制御が最も重要な要素であり, 再現性に優れた膜密 度制御が大きな問題となっていた。我々は本特徵を逆手に 取り, 膜密度制御に優れたインクジェット法の利点を活か した素子作製を試みた。具体的には，SWCNT 薄膜におけ る膜密度の高精度制御を目指して, 低濃度 SWCNT インク を用いた膜密度のインク滴下回数依存性を明らかにした。 原理的には箇所あたりの滴下回数が多い高密度 SWCNT 薄 膜の電極と滴下回数が少ない低密度 SWCNT 薄膜の半導体 を組み合わせたトランジスタが実現できる14。Figure 4 は, 実際に我々が作製したトランジスタを示しており，SWCNT とインクジェット技術の組み合わせならではの『分子の特 徵を活かした機能性素子の実現』に成功している。 


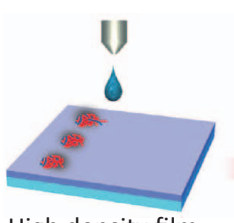

High density film (Electrodes)

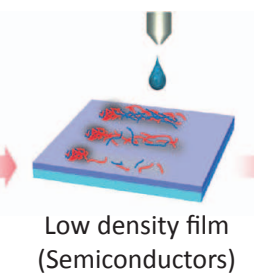

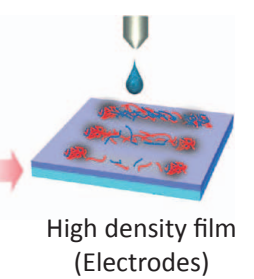
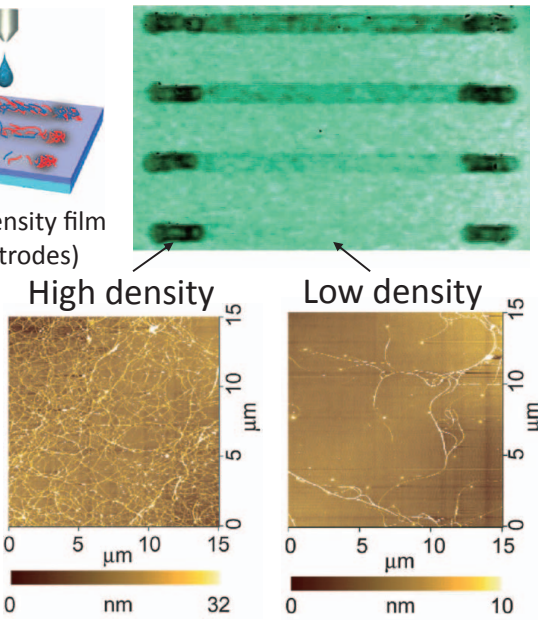

Figure 4. Density controlled SWCNT thin films produced by inkjet printing technique.

\section{Flexible Electronics}

\subsection{Flexible electronics とは}

近年, スマートフォンの爆発的な普及によりインター ネット接続可能な電子機器をストレスなく携帯する技術の 重要性が明確となった。携帯性の更なる向上には衣服の様 な柔軟性・伸縮性を有する素子作製技術の構築が不可欠で あり，文字通りウェアラブル・コンピューティングを体現 した魅力的な電子機器が必要である。例えば, Google 社は 眼鏡型端末（Google glass）を, Apple 社は時計型端末 (Apple Watch) を市場に投入している。これらは単なる既 存技術の拡張であるが，機器としての性能ではなく携帯性 の高さ等の物理的なインターフェイスが次世代の鍵である 事を如実に示している。携帯性の更なる高機能化には衣服 の様な柔軟性・伸縮性を有する素子が不可欠であり，材 料・プロセス技術の両側面からの革新的なアプローチによ る多機能・高性能素子作製技術確立が焦眉の急である。つ まり，これまでのガラスやシリコンのような硬い基板では なく，可撓性や伸縮性を有する基板上での素子作製が求め られる。ここまでに, printed electronicsの利点として低コ スト・省エネルギー・低環境負荷などをあげたが，これら に加えて印刷技術には低温プロセスならではの基板選択の 自由度があり，可撓性や伸縮性を有する次世代のエレクト ロニクス (flexible electronics · stretchable electronics • wearable electronics）への発展が期待されている。例えば，プラ スチック基板上に発光素子とトランジスタを作り込み，フ レキシブルなディスプレイを作製するアイデアが有機 EL 研究の初期段階から注目されていた。有機 EL テレビが実 用された今, 関係研究者の次なるターゲットはフレキシブ ルディスプレイ実現となりつつある。それ以外にも，RF-ID タグなど様々な応用が検討されている。また，プラスチッ ク基板上における素子作製は，柔軟性だけでなく軽量化や 耐衝撃性向上などガラス基板にはない様々な利点があり, 活発な研究が行われている。

Flexible electronics を実現するには，基板だけでなく材料

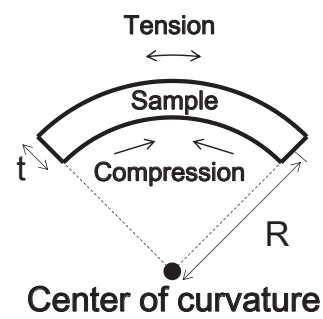

Strain 100 $\times t / 2 R(\%)$

Figure 5. Schematic representation of induced strain in flexible sample.

にも柔軟性が求められる。強固な結合を有する無機材料に 比ベ，柔らかいファンデルワールス結合からなる分子性固 体は，より flexible electronicsに適した材料として注目され ている。しかしながら, 通常の材料は $1 \%$ 程度の構造歪み により伝導機能を大幅に損なうため，優れた柔軟性・伸縮 性の実現は歪み対策が最も重要である。例えば，薄膜試料 (厚み $t$ ) をある曲率半径 $(R)$ にて湾曲させると，曲率中 心から見て試料の内側と外側は内周と外周の差から歪みが 生じる (Figure 5)。そのため, 材料を曲げる行為は歪みを 導入する事と等価であり，flexible electronicsの最も大きな 問題となる。東京大学の染谷隆夫教授は厚み方向の中心部 分では歪が生じない事に着目し，プラスチック基板二枚を 張り合わせた間への素子作製により柔軟性に優れた素子作 製に成功している ${ }^{15}$ 。筆者らのグループは，より簡便な素 子構造に扮ける柔軟性実現を目指し，SWCNT 薄膜を用い た材料面からの解決を試みた。

\subsection{SWCNT flexible electronics}

SWCNT の大きな特徵は，硬さとしなやかさの共存であ る。SWCNT は極めて強固な炭素間共有結合により形成さ れるため優れた硬性を有しており，特に長軸方向のヤング 率はダイヤモンドのそれに匹敵する。しかしながら，筒状 構造のため丈夫でありながら柔軟性を有しており，非常に 大きな曲げや歪みに対して欠陥を生じることなく元の構造 

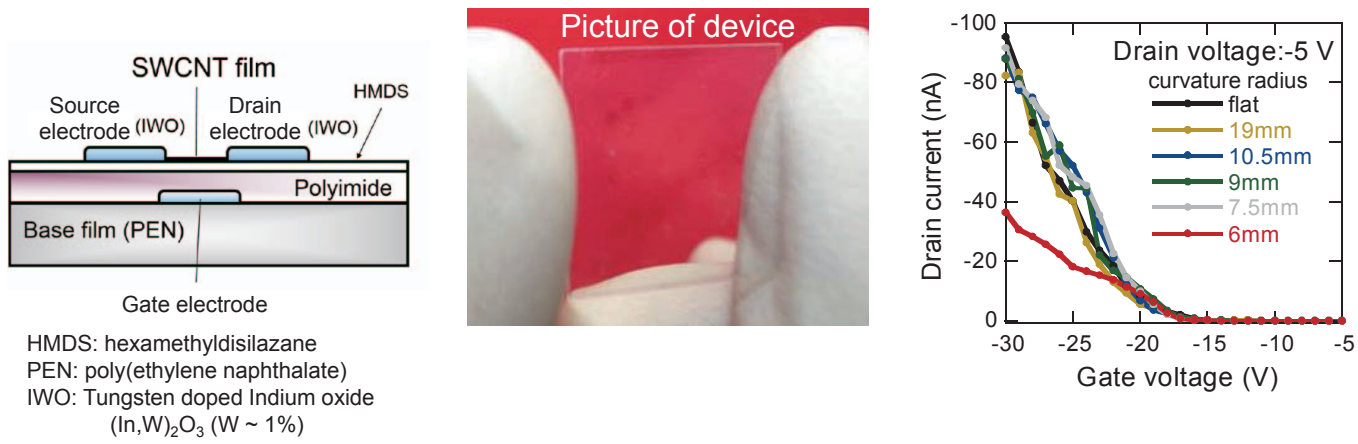

Figure 6. Solution processed flexible and transparent SWCNT thin film transistor.

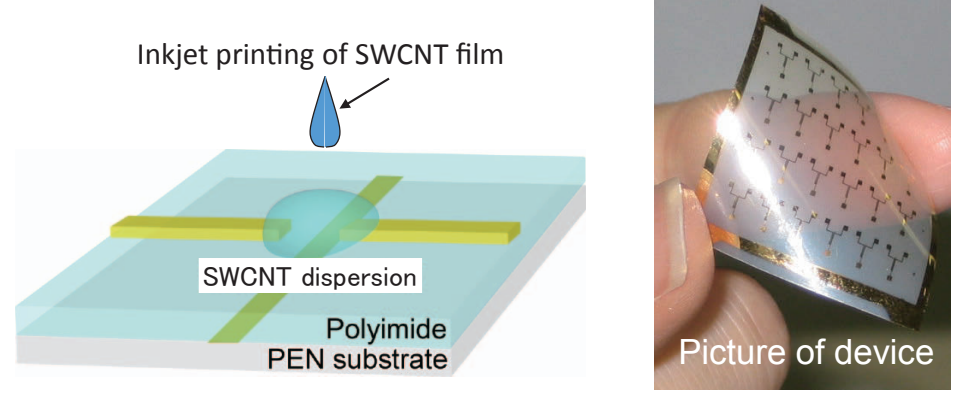

Figure 7. Inkjet printing of flexible SWCNT thin film transistor.

に復元する。つまり，何があっても切れない極細・極薄の ゴムホースのような材料であり, 引張りには極めて強いが 曲げに対しては非常にしなやかな特徴を有している。この 点が，類似の形状を有するナノロッドとの機械的特性から 見た本質的な違いである。そのため，ホースの中を流れる 水のようにフレキシブルに電流を流す。加えて, SWCNT 薄膜におけるSWCNT 間相互作用は柔らかいファンデル ワールス結合であり, 高分子材料と同様に歪みに対して弾 性変形と塑性変形が共存する柔軟な構造変化が可能である。 また，SWCNTの表面は全く立体構造を持たない平面であ るため，SWCNT表面におけるスライディングにより SWCNT 間接点抵抗は変形に大きく影響されないと期待さ れ，そもそも塑性変形による抵抗変化が小さいと考えられ る。このような特徴に注目し，プラスチック基板上での素 子作製を試みた。

前述したようにSWCNT インクを用いた素子作製が可能 であり，第一段階としては本手法をプラスチック基板に適 用した ${ }^{16}$ 。具体的には, ポリエチレンナフタレート（PEN） 基板上にポリイミド絶縁膜と酸化物透明電極（タングステ ンを $1 \%$ ドープしたインジウム酸化物，IWO）を作製し， 最後にSWCNT 分散液を滴下・乾燥させた。Figure 6 に示 すように, 全ての部材（電極・絶縁体・基板）に透明な材 料を用いた。写真では確認が難しいが，プラスチックの基 板上に数十の素子が作製されている。作製した素子はトラ ンジスタ特性を示し, 柔軟性試験の結果より曲率半径 7.5 $\mathrm{mm}$ までは安定な動作を示した。また, 曲率半径 $6 \mathrm{~mm}$ で は特性劣化が見られたが, 詳細な調査の結果より劣化原因
はSWCNT 薄膜の限界ではなく酸化物透明電極（IWO）の 曲率限界であることが明らかとなった。このような透明フ レキシブルトランジスタはディスプレイ応用としても魅力 的であり，非常に多くの光が取り出せる事を意味する。次 に，インクジェット法を用いた flexibleトランジスタ作製も 試み（Figure 7)，トランジスタ動作の実現に成功してい る ${ }^{13}$ 。後述するが, 最近の研究ではインクジェット法と電 解質を用いて作製したSWCNT 薄膜トランジスタが曲率半 径 $0.1 \mathrm{~mm}$ における安定駆動を実現しており, flexible electronics の担い手としての SWCNT が持つ潜在能力を明らか にしている。これらは, 極めてユニークな構造に由来する 材料自体の柔軟性と薄膜における塑性変形が優れた柔軟性 の起源であると考えられ，『分子の特徴を活かした機能』の 一つと言える。

\section{5. 電解質を用いた SWCNTトランジスタ \\ 5.1 半導体的 SWCNT 薄膜の謎}

前節までに，SWCNTを用いた printed electronics および flexible electronics が実現可能であり，優れた特性が実現さ れることを説明した。しかしながら，SWCNTは構造によ り金属にも半導体にもなり得るため, 半導体的な伝導特性 を得るには精細な膜密度制御が必要である。確かに, イン クジェット法を用いた濃度制御が可能ではあるが，根本的 な解決となる金属的 SWCNT と半導体的 SWCNT の選択的 合成法もしくは分離方法の確立が強く期待されていた。こ のような状況に対して様々な方法が提案され，特に国内グ ループである産業技術総合研究所・片浦弘道博士や柳和宏 


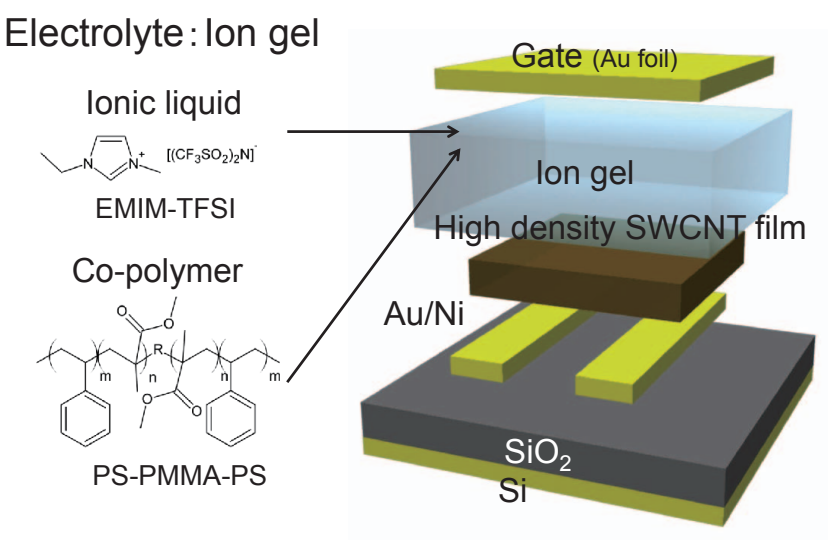

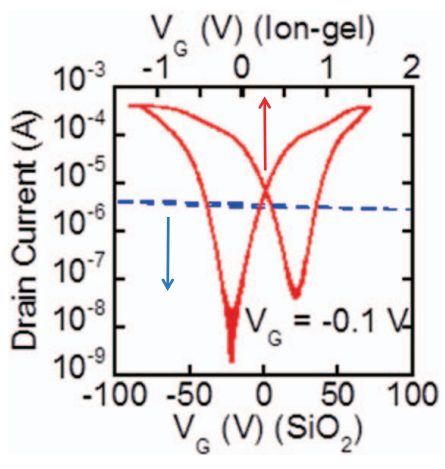

Blue: $\mathrm{SiO}_{2}$ gating

Red:Electrolyte gating

Figure 8. Electrolyte gated SWCNT film transistor.

博士（現 首都大学東京准教授）らが分離方法を確立し, 純度 $99 \%$ 以上の金属的もしくは半導体的 SWCNT が得られ るようになった ${ }^{17-19}$ 。この成功を受け，多くの研究者が高 密度な半導体的 SWCNTを用いたトランジス夕作製を試み たが，残念ながら大きな問題を突き付けられた。当然，金 属的 SWCNT と半導体的 SWCNT の高純度分離が実現すれ ば SWCNT 薄膜に対する濃度制御は不要と思われてきたが, 高密度な半導体的 SWCNT は『金属的な』振る舞いを示し, 低密度な半導体的 SWCNT 薄膜のみがトランジス夕特性を 示した ${ }^{20,21}$ 。つまり, 分離したにもかかわらず, 分離前と 変わらない密度制御を必要とし, 関連の研究者に大きな衝 撃を与えた。

\section{2 電解質を用いた SWCNT トランジスタ}

高度に分離されたSWCNT における膜密度依存性は長ら く大きな謎であったが，意外にも電解質を用いた実験によ り理由が明らかとなった。実験結果を基に説明する。Figure 8 に, 高密度な半導体的 SWCNT を用いたトランジスタを 示す。ここでは, 高ドープの Si を熱酸化させた基板を用い ている。Si は半導体であるが, 高密度にドープされている ため高ドープの Si は室温において金属的な振る舞いをし, ここではゲート電極として使用している。絶縁体である $\mathrm{SiO}_{2}$ を挟んで金属的な $\mathrm{Si}$ (ゲート電極）と高密度半導体的 SWCNT が位置しており，これらはコンデンサの役割を果 たす。ゲート電極／SWCNT 間に電圧（この電圧をゲート 電圧と呼ぶ）を印可すると, $\mathrm{SiO}_{2} /$ 半導体的 SWCNT の界 面に電荷が蓄積され, 半導体的 SWCNT の電気抵抗変化が 期待される。この抵抗変化を調べるために, SWCNT 薄膜 には二つの電極（ソース電極・ドレイン電極）が形成され ている。ソース・ドレイン電極間に定電圧（ドレイン電圧） を印可しながらソース・ドレイン電極間電流のゲート電圧 依存性を測定すると（Figure 8, 青い点線），一見して分か るように電流はほとんど変化しておらず, キャリア蓄積の 効果が見られない。本稿では，このような振る舞いを『金 属的』と呼んでいる。一方, 同一の半導体的 SWCNT 薄膜
に電解質（ゲル化させたイオン液体）を塗布し，ゲート電 極として金䇴を用いた結果を同じく Figure 8 (赤い実線) に 示す。驚くべきことに，同一SWCNT 薄膜であるにも関わ らず, $\mathrm{SiO}_{2}$ を用いた場合とは異なり数桁にもわたる抵抗変 化が観測された。 $\mathrm{SiO}_{2}$ を用いた場合と電解質を用いた場合 では単位面積当たりの静電容量が 3 桁以上異なっており, 本実験から得られた違いは半導体的 SWCNT にドープされ ているキャリアが起源と解釈される。つまり， $\mathrm{SiO}_{2}$ を用い た場合, 半導体的 SWCNT 薄膜が低密度な場合はドープ キャリアを電界効果により排除（空乏化）することが可能 であり, トランジスタ特性が得られる。一方で, SWCNT が高密度な場合は単位面積あたりに SWCNT 薄膜が有する 総キャリア数が, $\mathrm{SiO}_{2}$ の静電容量と印可可能なゲート電圧 から求まるコンデンサが変調可能なキャリア数を超えてお り，完全な空乏化が難しく金属的な振る舞いをする。これ とは対照的に，電解質を用いると極めて大きな静電容量に より SWCNT の膜密度に関わらず完全な空乏化が可能であ り, 半導体的な特性が得られる。これらより得られる重要 な知見として，一つに電解質を用いることで高純度に分離 された半導体的 SWCNT を有効に使用できることがあげら れる。

\section{3 電解質を用いたトランジスタの駆動原理と特徵}

電解質を用いたトランジスタの駆動原理に関して, 簡単 に説明する。このようなトランジスタは決して新しいわけ ではなく, 『電気化学ドーピング』として高分子材料を中心 に古くから多くの研究がされている。さらに，原理まで踏 み込むと 1879 年にヘルムホルツが発見した電解質に特有な 電気二重層に帰着する 1 。言うまでもなく，電気二重層と は比較的自由に動ける荷電粒子（イオン）が酸化還元電位 以下の電場下において電極方向に移動し, 電極表面におい てシート状に整列した状態を指す。重要な点として, 電極 内では荷電粒子と反対符号の電荷が対をなして整列してお り, 結果として二重構造となる。重要な特徵として, 対を なす電極間の距離が nm スケールであり，通常の絶縁体に 


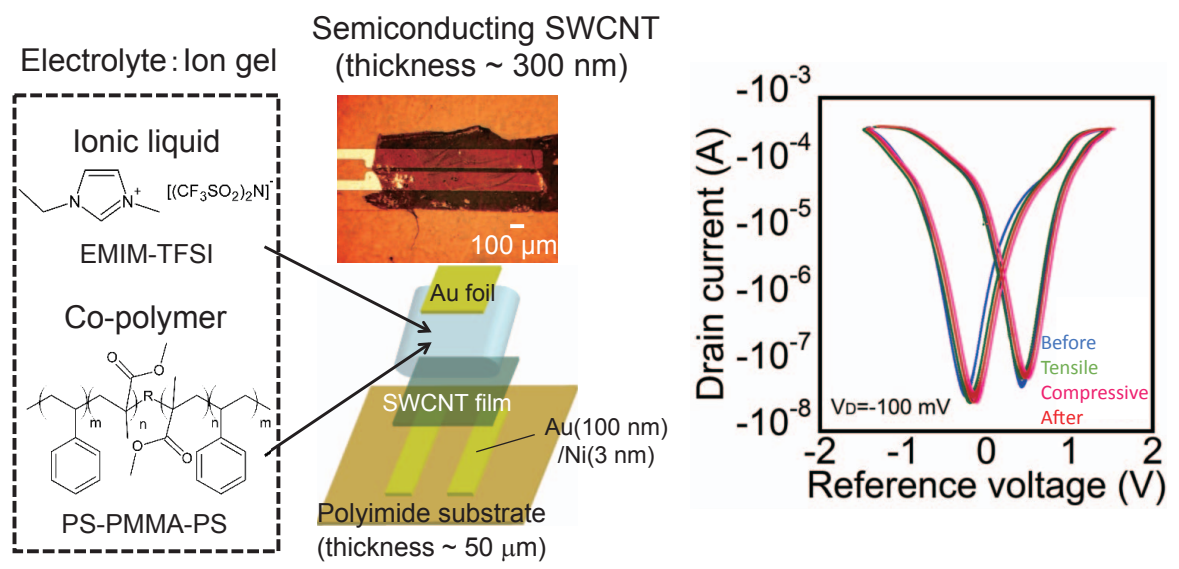

Figure 9. Electrolyte gated flexible SWCNT thin film transistor.

比べ 3 桁近く大きな静電容量を有する。そのため, 小さな 印可電圧で大きなキャリア数変化を引き起こせる。電気二 重層を用いた固体素子は, 古くは 1946 年のベル研究所にお ける研究でも知られているが, 近年では冒頭で述べたヤ ン・ヘンドリック・シェーンと同じコンセプトの基で物性 研究に用いられ華々しい成果が挙げられている。このよう な電気二重層の SWCNT 薄膜トランジスタにおける役割を 説明する。

SWCNT や高分子材料では, 『電気二重層トランジスタ (Electric double layer transistor, EDLT)』よりも『電気化学 トランジスタ (Electrochemical transistor, ECT)』や『電解質 ゲートトランジスタ (Electrolyte gated transistor, EGT)』と いう表記が用いられる。EDLTの場合，平坦な表面を有す るトランジスタを用い, その表面に電気二重層を形成し キャリア数制御を行う。あくまで，イオンと半導体が接す るのは表面だけであり, 材料自体は構造的な変化を受けな いため，伝導特性に影響を与えることなくキャリア数のみ 変化できるのが利点である ${ }^{22,23}$ 。一方, ECT の場合は, 材 料内部にイオンが浸透し全ての SWCNT や高分子表面に電 気二重層が形成される。そのため, 膜全体のキャリア数が 大きく変化する ${ }^{24,25}$ 。このような特徵は, SWCNT 薄膜か ら余分なキャリアを排出する上で極めて効果的である。こ れと同時に，ECTにおいては SWCNT 間や高分子間の構造 や相互作用にも変化され，機械的特徵にも影響がある。一 概には言えないが，イオン的な相互作用が加わるため材料 自体の粘性が変化し，より可撓性や伸縮性に優れる傾向が ある。加えて, 多くの電解質は液体もしくは可溶性を有す る為，印刷技術の導入も容易である。つまり，電解質を用 いたトランジスタは機械的な特徴に限定すると次世代のエ レクトロニクス (printed electronics · flexible electronics · stretchable electronics · wearable electronics）に最適な素子構 造と言える。

\section{6. 電解質を用いた新しい SWCNT トランジスタ}

前節で説明したように電解質を用いた SWCNTトランジ
スタは次世代のエレクトロニクス (printed electronics・flexible electronics $\cdot$ stretchable electronics $\cdot$ wearable electronics) に最適な素子構造と考えらえる。そこで，まず最も簡便な 印刷技術である転写法を用いて柔軟なトランジスタの作製 を試みた。素子構造を Figure 9 に示す。あらかじめソース 電極とドレイン電極をプラスチック（ポリイミド）基板上 に蒸着し，その上に高密度・高純度な半導体的 SWCNT 薄 膜を転写する。薄膜作製のために，半導体的 SWCNT の分 散液を準備し，吸引濾過によりフィルター上に SWCNT 薄 膜を作製する。SWCNT 薄膜をフィルターごとハサミで加 エし，ソース・ドレイン電極間に設置した後に，フィル ターをアセトンにより洗い流した。ポリイミド基板上の SWCNT 薄膜にイオン液体をゲル化したイオンゲルを塗布 し，最後にゲート電極用の金箔をゲル上に設置すれば素子 作製が終了である。ソース・ドレイン電極以外は，真空製 膜を用いていない。このように作製した SWCNT トランジ ス夕は Si 基板上と遜色ない特性を示した。加えて，基板を 湾曲させ引張歪および圧縮歪を導入したが，限界まで湾曲 させても（曲率半径 $0.2 \mathrm{~mm}$ ）特性の劣化は観測されなかっ た。湾曲時には, 必ず SWCNT 薄膜に歪みが生じているは ずだが，優れた機械特性により影響が観測されなかった。

次に，インクジェット法を用いた完全塗布型トランジス 夕作製を試みた。まず，高度に分離された金属型 SWCNT および半導体型 SWCNT を準備し，DMFに分散させたイン クを準備する。加えて，イオン液体およびゲル化用の高分 子を溶解させたイオンゲルインクも準備した。これら 3 種 類のインクを用いてトランジスタを作製すため, DMF 分散 液が吐出可能な薬品耐性に優れたインクジェット装置を準 備した。今や，素子作製に必要なのは基板のみである。今 回は，ポリイミド基板を準備した。Figure 10 に示すように， 電極用の金属的 SWCNT インク，活性層用の半導体的 SWCNT インク，絶縁体用のイオンゲルインクを順に滴下 し，素子作製を行った。得られたトランジスタは，転写法 で作製したトランジス夕同様，優れたトランジス夕特性と 柔軟性が得られた。前述したように（Figure 5)，薄膜材料 


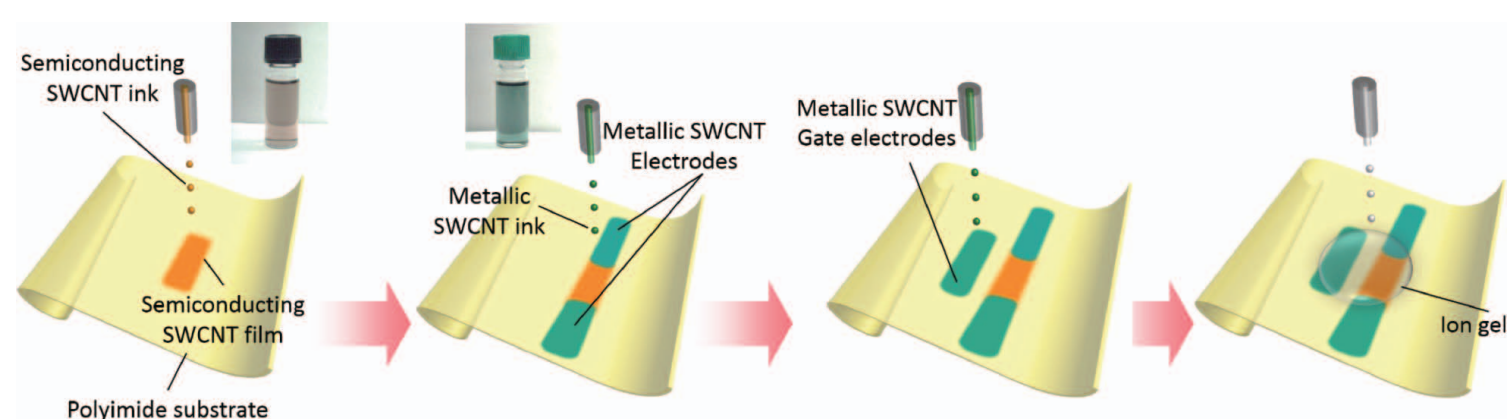
(thickness: $7.5 \mu \mathrm{m}$ )
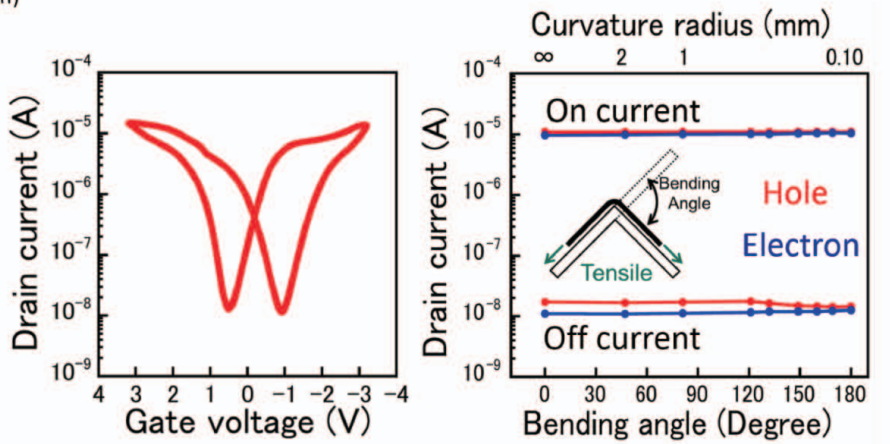

Figure 10. Inkjet printing of electrolyte gated flexible SWCNT thin film transistor.

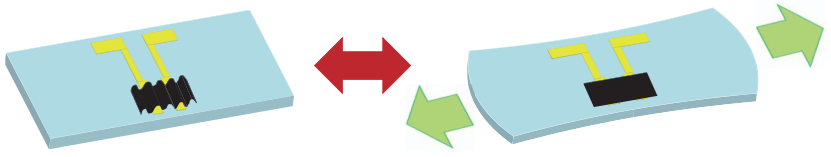

Figure 11. Schematic representation of stretchability in accordion-like SWCNT film.

の湾曲時に誘起される歪は膜厚に比例する。そのため, 本 実験では厚み $50 \mu \mathrm{m}$ の極薄なポリイミド基板を用いた。そ の結果, 曲率半径 $0.1 \mathrm{~mm}$ まで特性の劣化が観測されず，極 めて優れた機械的特性が得られた。

以上のように，電解質を用いた SWCNTトランジスタの 優れた機械的特性が確認された。歪を避ける構造を導入す ることなく，このような柔軟性や伸縮性が得られることは 驚くべき結果であり，並行して起源の解明も試みられてい る。今後, 機械的特性の更なる解明とともに, より最適化 された特性が来期待される。近年では, 優れた柔軟性を活 かして伸縮性を有する基板上に波状の構造（アコーディオ ン状の構造）を有する SWCNT 薄膜を作製し，伸縮性トラ ンジスタの試作が著者らのグループを含め試みられており， 数十\%の伸縮性が実現している（Figure 11）。

\section{7. 今後の発展とまとめ}

SWCNTを用いた新しい機能性素子に関して紹介した。特 に，後半では電解質を組み合わせた素子が次世代のエレク トロニクス (printed electronics · flexible electronics $\cdot$ stretchable electronics · wearable electronics）で必要とされる特徵 を有していることを解説した。一方で, 良く知られるよう に電気化学ドーピングは応答速度が非常に遅い。機械的特 性に優れた SWCNT トランジスタも，このままでは実デバ
イスとしての利用は不可能である。越えなければならない 壁は大きいが, その先には大きな実りがあり, 多くの研究 者の参入を期待したい。

本稿で紹介した考え方は, 単に電気化学反応時における 機械的特性の観察と言い換えることができる。電気化学 ドーピングによる抵抗変化は決して新しくなく，イオンと 高分子の混合物における機械的特性の変化にも新たな知見 は多くない。しかしながら，これらはファンデルワールス 結合により形成された柔らかな分子性固体の特徴であり， 両者の組み合わせは『分子の特徵を活かした機能性素子の 実現』において極めて効果的に㗢いた。理由としては，工 レクトロニクスに対する社会的要請が大きく変化している ことがあげられる。また, 基板となる可撓性材料や伸縮性 材料が材料科学の進展により豊富に存在し, 印刷技術の発 展によりインクジェット技術が極めて簡便となるなど，科 学技術のめまぐるしい進歩も重要であった。まさに, 今だ からこそ実現した新機能であると考える。分子性固体にお ける長く深い研究の歴史を鑑みると，『分子の特徵を活かし た機能性素子の実現』へとつながる既知のユニークな特性 が数多く眠っていると考えるのが自然であろう。本稿にて 紹介したコロンブスの卵的発想により，高度に情報化され た現代社会だからこそ必要とされる様々な新しい機能の実 現が期待される。

SWCNT を用いた新しい機能性素子作製は, 多くの共同研究者と の共同研究である。全ての共同研究者に㧍礼申し上げたい。特に, 岩佐義宏教授 (東京大学), 下谷秀和准教授 (東北大), 柳和宏准 教授 (首都大学東京), 沖本治哉助教 (山形大学), 片浦弘道博士 （産業総合技術研究所）に, この場を借りて心より感謝申し上げた い。 
また, 本稿で紹介した研究成果は, 内閣府最先端次世代研究開 発支援プログラム『超高性能インクジェットプリンテッドエレク トロニクス』, NEDO 先導的産業技術創出事業（若手研究グラント） 『インクジェット法を用いたカーボンナノチューブ薄膜トランジス タの創製と透明フレキシブルトランジスタへの展開』, JST-ALCA 『超省資源ナノチューブフレキシブルエレクトロニクス』, 文部科 学省科学研究費補助金新学術領域研究『 $\pi$ 造形システム集合体の 物性制御』(No 26102012), 文部科学省科学研究費補助金特別推進 研究『イオントロニクス学理の構築』(No 25000003) の支援を受 けて実施し得られたものである。

\section{引用文献}

(1) von Helmholtz, H. L. F. Ann. Phys. Chem. 1879, 7, 337-382.

（2）岩佐義宏，竹延大志，応用物理 2008, 77, 432-437.

(3) Cao, Q.; Rogers, J. A. Adv. Mater. 2009, 21, 29-53.

(4) Iijima, S. Nature 1991, 354, 56-58.

(5) Iijima, S.; Ichihashi, T. Nature 1993, 363, 603-605.

（6）篠原久典監修, ナノカーボン材料開発の新局面; シーエム シー出版 : 東京, 2003, 38-43.

(7) Saito, R.; Fujita, M.; Dresselhaus, G.; Dresselhaus, M. S. Appl. Phys. Lett. 1992, 60, 2204-2206.

(8) Tans, S. J.; Verschueren, A. R. M.; Dekker, C. Nature 1998, 393, $49-52$.

(9) Snow, E. S.; Novak, J. P.; Campbell, P. M.; Park, D. Appl. Phys. Lett. 2003, 82, 2145-2147.

(10) Sun, D.-M.; Timmermans, M. Y.; Kaskela, A.; Nasibulin, A. G.; Kishimoto, S.; Mizutani, T.; Kauppinen, E. I.; Ohno, Y. Nat. Cоттип. 2013, 4, 2302.

(11) Sun, D.-M.; Timmermans, M. Y.; Tian, Y.; Nasibulin, A. G.; Kauppinen, E. I.; Kishimoto, S.; Mizutani, T.; Ohno, Y. Nat. Nanotechnol. 2011, 6, 156-161.

(12) Shiraishi, M.; Takenobu, T.; Iwai, T.; Iwasa, Y.; Kataura, H.; Ata,
M. Chem. Phys. Lett. 2004, 394, 110-113.

(13) Takenobu, T.; Miura, N.; Lu, S.-Y.; Okimoto, H.; Asano, T.; Shiraishi, M.; Iwasa, Y. Appl. Phys. Express 2009, 2, 025005.

(14) Okimoto, H.; Takenobu, T.; Yanagi, K.; Miyata, Y.; Shimotani, H.; Kataura, H.; Iwasa, Y. Adv. Mater. 2010, 22, 3981-3986.

(15) Kaltenbrunner, M.; Sekitani, T.; Reeder, J.; Yokota, T.; Kuribara, K.; Tokuhara, T.; Drack, M.; Schwödiauer, R.; Graz, I.; Bauer-Gogonea, S.; Bauer, S.; Someya, T. Nature 2013, 499, $458-463$.

(16) Takenobu, T.; Takahashi, T.; Kanbara, T.; Aoyagi, Y.; Iwasa, Y. Appl. Phys. Lett. 2006, 88, 033511.

(17) Arnold, M. S.; Green, A. A.; Hulvat, J. F.; Stupp, S. I.; Hersam, M. C. Nat. Nanotechnol. 2006, 1, 60-65.

(18) Yanagi, K.; Miyata, Y.; Kataura, H. Appl. Phys. Express 2008, 1, 034003.

(19) Liu, H.; Nishide, D.; Tanaka, T.; Kataura, H. Nat. Commun. 2011, 2, 309 .

(20) Rouhi, N.; Jain, D.; Burke, P. J. ACS Nano 2011, 5, 8471-8487.

(21) Fujii, S.; Tanaka, T.; Miyata, Y.; Suga, H.; Naitoh, Y.; Minari, T.; Miyadera, T.; Tsukagoshi, K.; Kataura, H. Appl. Phys. Lett. 2009, 2, 071601 .

(22) Hwang, H. Y.; Iwasa, Y.; Kawasaki, M.; Keimer, B.; Nagaosa, N.; Tokura, Y. Nat. Mater. 2012, 11, 103-113.

（23）岩佐義宏, 下谷秀和, 応用物理 2015, 84, 306-318.

(24) Shimotani, H.; Tsuda, S.; Yuan, H.; Yomogida, Y.; Moriya, R.; Takenobu, T.; Yanagi, K.; Iwasa, Y. Adv. Funct. Mater. 2014, 24, 3305-3311.

(25) Yanagi, K.; Moriya, R.; Yomogida, Y.; Takenobu, T.; Naitoh, Y.; Ishida, T.; Kataura, H.; Matsuda, K.; Maniwa, Y. Adv. Mater. 2011, 23, 2811-2814.

\footnotetext{
竹延 大志 (たけのぶ たいし)

所属: 早稲田大学先進理工学部応用物理学科

専門分野：材料科学, デバイス物理学

連絡先：03-5286-2981

電子メール：takenobu@waseda.jp

URL : http://www.f.waseda.jp/takenobu/index.html
} 